\title{
Cytotoxic effects of Pseudocerastes persicus venom and its HPLC fractions on lung cancer cells
}

\author{
Benyamin Shahbazi ${ }^{1}$, Zahra Salehi Najafabadi 2,* (D), Hamidreza Goudarzi², \\ Mahnaz Sajadi ${ }^{3}$, Fatemeh Tahoori² ${ }^{2}$ Masoumeh Bagheri ${ }^{2}$ \\ ${ }_{1}$ Payame Noor University of Tehran Shargh, Tehran, Iran. \\ ${ }^{2}$ Razi Vaccine and Serum Research Institute, Agricultural Research, Education and Extension Organization, Karaj, Iran. \\ ${ }^{3}$ Tofigh Daru Research and Engineering Company, Tehran, Iran.
}

\section{Keywords:}

Pseudocerastes persicus venom

Persian horned viper

HPLC fractions

Cytotoxicity

Apoptosis

\begin{abstract}
Background: Several studies have pointed out that certain snake venoms contain compounds presenting cytotoxic activities that selectively interfere with cancer cell metabolism. In this study, Pseudocerastes persicus venom and its fractions were investigated for their anticancer potential on lung cancer cells.

Methods: Lung cancer cells (A549) and normal fibroblast cells (Hu02) were treated with the P. persicus venom and its HPLC fractions and the cell cytotoxic effects were analyzed using MTT and lactate dehydrogenase release assays. Apoptosis was determined in venom-treated cell cultures using caspase- 3 and caspase-9 assay kits.

Results: The treatment of cells with HPLC fraction $21(25-35 \mathrm{kDa})$ of $P$. persicus venom resulted in high LDH release in normal fibroblast cells and high caspase- 3 and caspase- 9 activities in lung cancer cells. These results indicate that fraction 21 induces apoptosis in cancer cells, whereas necrosis is predominantly caused by cell death in the normal cells. Fraction 21 at the final concentration of $10 \mu \mathrm{g} / \mathrm{mL}$ killed approximately $60 \%$ of lung cancer cells, while in normal fibroblast cells very low cell cytotoxic effect was observed. Conclusion: HPLC fraction 21 at low concentrations displayed promising anticancer properties with apoptosis induction in the lung cancer cells. This fraction may, therefore, be considered a promising candidate for further studies.
\end{abstract}

* Correspondence: zahra.salehi@live.com http://dx.doi.org/10.1590/1678-9199-JVATITD-2019-0009 Received: 27 February 2019; Accepted: 6 August 2019; Published online: 16 Septembre 2019 


\section{Background}

Snake venom is a highly complex mixture of organic and inorganic compounds that include peptides, enzymes, lowmolecular mass proteins that have specific chemical and biological activities and non-protein inclusions [1,2]. There are many venom-derived drugs on the market against different types of human diseases, some examples are captopril and enalapril against hypertension, ziconotide for management of severe chronic pain and batroxobin for acute cerebral infarction $[3,4]$.

Undoubtedly, cancer is one of the primary causes of human deaths worldwide [5,6]. It can be treated with surgery, chemotherapy and/or radiation, targeted therapy, immunotherapy and even nonselective cytotoxic drugs [7]. Therefore, the investigation and discovery of new drugs for treatment of cancer are the objectives of research in biotechnology $[8,9]$. Numerous studies, in phase I and phase II of clinical trials, using advanced proteomics and genomics approaches described that venom peptides can induce cytotoxic effects and apoptosis on cancer cell lines are $[3,10]$. Cytotoxins are one of the most important toxins isolated from various snake venoms and they alter the cellular metabolism through interaction with specific cellular receptors, damaging the cell membranes or blocking the ion channels or the signal transduction pathways [11]. Ion channels targeting cancer cells include polycystin complexes [12], chloride channels, sodium channels and potassium channels $[3,10]$.

The enzymes and proteins with promising anticancer activities include phospholipases $\mathrm{A}_{2}$ (cytotoxicity), L-amino acid oxidases (LAAOs - apoptosis), metalloproteinases (inhibitor of cell proliferation), peptides such as cardiotoxin III (antiangiogenic) and cytotoxin P4 (cytotoxicity), cytotoxins CT1, CT2 and CT3 (cytotoxicity), lectins (cytotoxicity), disintegrins (anti-angiogenic), serineproteases such as ancrod (inhibitor of tumor growth) etc. [1,2].

The Persian horned viper Pseudocerastes persicus is a venomous viper species found in the Middle East and Asia. P. persicus venom exhibits strong hemorrhagic activity and is potently coagulopathic. Although there are some research on P. persicus venom composition, currently little information about specific activities of the venom is available.

In the present study, we investigated the cytotoxic induction capacity of $P$. persicus venom and its fractions on lung cancer cells and normal fibroblast cells in vitro.

\section{Methods}

\section{Materials and chemicals}

Dimethylsulfoxide (DMSO), Dulbecco's modified Eagle's medium (DMEM), penicillin-streptomycin (Pen-Strep), L-glutamine, fetal bovine serum (FBS), 3-(4, 5 dimethylthiazol-2-yl)-2,5- diphenyl-tetrazolium bromide (MTT), Bradford reagent and sodium bicarbonate were purchased from Sigma. Caspase-3 and caspase- 9 assay kits (Colorimetric) were purchased from Abcam, USA.

\section{Venom preparation}

Freeze-dried $P$. persicus snake venom was obtained from the department of venomous animals and antivenom production of Razi Vaccine and Serum Research Institute. Lyophilized venom was dissolved in sterile double-distilled water. After centrifugation at $4000 \mathrm{RCF}$ for $20 \mathrm{~min}$ at $4^{\circ} \mathrm{C}$, the supernatant was passed through $0.45 \mu \mathrm{m}$ nitrocellulose filter (MilliporeSigma, USA) and the protein concentration was examined by Bradford method.

\section{Cell lines and cell culture}

Lung cancer cells (A549) and normal fibroblast cells (Hu02) were purchased from Iranian Biological Resource Center. Above cells were cultured in T75 cell culture flask containing DMEM medium, 10\% FBS, 1\% Pen-Strep, 2 mM L-glutamine. Cells were subcultivated using trypsin-EDTA (0.05\% trypsin) in 96-well plates (Corning, USA) at a density of 15000 cells/well in $100 \mu \mathrm{L}$ complete medium. All cells were incubated overnight at $37^{\circ} \mathrm{C}$ with $5 \% \mathrm{CO}_{2}$ in a humidified incubator.

\section{In vitro cytotoxicity assay}

Cytotoxicity of the $P$. persicus venom was examined by colorimetric MTT assay [13,14]. The cells were subcultivated in three 96-well plates as mentioned before. Following overnight incubation, fresh complete medium with different concentrations of venom $(0,1,3,5,10,15,18,20,30,50 \mu \mathrm{g} / \mathrm{mL})$ were added to the wells in triplicate. The cells were harvested after treatment of 24 and 48 hours.

The culture media was removed and the wells were washed by adding $100 \mu \mathrm{L}$ of PBS buffer per well and the PBS was immediately removed. Then, $100 \mu \mathrm{L}$ of DMEM medium without FBS and $20 \mu \mathrm{L}$ MTT $(5 \mathrm{mg} / \mathrm{mL})$ was added to each well and the plates were incubated at $37^{\circ} \mathrm{C}$ in the dark for two hours. MTT is a tetrazolium dye that is reduced by specific mitochondrial enzymes (in the live cells) to formazan, an insoluble crystalline product. After incubation, the wells were washed again with PBS buffer. One hundred microliters of DMSO was added to each well and the plate was shaken for $5 \mathrm{~min}$ in the dark in order to dissolve the formazan crystals to deep purple color. Thirty microliters of glycine buffer $(0.1 \mathrm{M}$ glycine, $0.1 \mathrm{M} \mathrm{NaCl}$, $\mathrm{pH}$ 10.5) was then added to each well and the absorbance was measured at $570 \mathrm{~nm}$ using a plate reading spectrophotometer (Bio-Rad Laboratories, USA). This assay was also employed to 
assess the half-maximal inhibitory concentration value $\left(\mathrm{IC}_{50}\right)$ of the venom in each cell line.

\section{Assay to measure caspase- 3 and caspase-9 activities}

The activities of caspase- 3 and caspase- 9 were evaluated using the colorometric Caspase-3 (\#ab39401, Abcam, USA) and Caspase-9 (\#ab65608, Abcam, USA) assay kits according to manufacturer's instructions. In brief, the cells were cultured in T25 flasks and were treated with $\mathrm{IC}_{50}$ concentrations of crude venom and they were collected at 12, 24 and 48 hours.

The cells were harvested and homogenized in lysis buffer. After that, $200 \mu \mathrm{g}$ of each lysate was mixed with $2 \times$ reaction buffer, DTT and substrate. The mixture was incubated at $37^{\circ} \mathrm{C}$ for two hours. Substrate cleavage was measured using a spectrophotometer at 400 or $405 \mathrm{~nm}$. The caspase activity in an apoptotic sample increases due to cleavage product, comparing an uninduced control.

\section{Lactate dehydrogenase release assay}

Lactate dehydrogenase (LDH) is an enzyme that is released into extracellular space when the plasma membrane is damaged. Therefore, measuring the amount of LDH release is a useful assay to discriminate between apoptosis and necrosis.

$\mathrm{Hu} 02$ and A549 cells were cultured in a 96-well plate and were treated in triplicates with 5, 10,20,30 $\mu \mathrm{g} / \mathrm{mL}$ HPLC fraction 21 for 24 hours. LDH activity was measured in $100 \mu \mathrm{L}$ of media overlaying the cells using LDH commercial kit (Pars Azmun, Iran) according to manufacturer's protocol. In order to measure the cytosolic $\mathrm{LDH}$, the cells in the wells were lysed with $100 \mu \mathrm{L}$ of $1 \%(\mathrm{v} / \mathrm{v})$ Triton X-100 and the cell lysates were assayed for LDH activity.

$$
\text { Percentage of released LDH }=\frac{\text { Released LDH (in the medium) }}{\text { Total LDH (in the medium and cell lysates) }}
$$

\section{Venom fractionation by RP-HPLC}

The lyophilized venom sample was dissolved in the sterile double-distilled water to achieve a final concentration of 5 $\mathrm{mg} / \mathrm{mL}$ and injected into a Waters $\mathrm{C} 18$ reversed phase HPLC column $(100 \AA, 5 \mu \mathrm{m}, 4.6 \times 150 \mathrm{~mm})$ equilibrated with solvent A (water/0.1\% TFA) at room temperature. The component of the venom was eluted at flow rate of $1 \mathrm{~mL} / \mathrm{min}$ with increasing the concentration of solvent B (acetonitrile/0.1\% TFA) using a step gradient program in 65 minutes. The absorbance of each component was monitored at $214 \mathrm{~nm}$ and the peaks were collected manually once identified by the detector. The fractions were lyophilized and reconstituted in DMEM medium and their cytotoxicity was analyzed as mentioned in the previous section.

\section{SDS-PAGE analysis}

SDS-PAGE analysis of crude venom and cytotoxic chromatographic fractions was performed under denaturating conditions using $12 \%$ polyacrylamide gel in the presence of DTT, according to the method described by Laemmli [15]. Protein bands were visualized by silver staining.

\section{Morphological studies}

Cells were subcultivated in a 96-well plate in complete DMEM medium and incubated at $37^{\circ} \mathrm{C}$ overnight. Subsequently, the cells were treated with different concentrations of venom for 24 hours and their morphological characterization was carried out using an inverted phase contrast microscope (Labomed TCM 400, USA).

\section{Data analysis}

$\mathrm{IC}_{50}$ was calculated using a dose-response curve. The difference between each experiment group and the control group was measured using an independent $\mathrm{t}$-test. Values were presented as means \pm standard deviation $(\mathrm{n}=3)$. Statistical significance is indicated as follows: ${ }^{\star} p \leq 0.05,{ }^{* *} p \leq 0.01$, and ${ }^{* *} p \leq 0.001$.

\section{Results}

\section{Effect of $P$. persicus crude venom on morphology of normal fibroblast and lung cancer cells}

Lung cancer A549 cells and normal fibroblast Hu02 cells were used for evaluation of the cytotoxic effects of $P$. persicus venom. Figure 1 shows the morphological changes of A549 and $\mathrm{Hu} 02$ cells 24 hours after incubation with $20 \mu \mathrm{g} / \mathrm{mL}$ and $30 \mu \mathrm{g} / \mathrm{mL}$ of the crude venom. Phase contrast images of untreated A549 cells exhibited regular polygonal cells with clearly define edge. After 24 hours of incubation with $20 \mu \mathrm{g} / \mathrm{mL}$ of venom, morphological abnormalities such as rounded cells, apoptotic bodies and loss of adhesion were observed in the cells (Figure 1A). These changes were associated with apoptosis in A549 cells. Untreated $\mathrm{Hu} 02$ cells exhibited a thin and elongated shape. Twenty-four hours after venom exposition, morphological alterations including membrane disruption, production of cellular debris and apoptotic bodies were observed in the $\mathrm{Hu} 02$ cells (Figure $1 \mathrm{~B}$ and $\mathrm{C}$ ). Observations 48 hours after treatment revealed an increased number of dead cells (data not shown).

Treatment of cells with higher doses of venom $(30 \mu \mathrm{g} / \mathrm{mL})$ caused growth inhibition and appearance of large areas devoid 

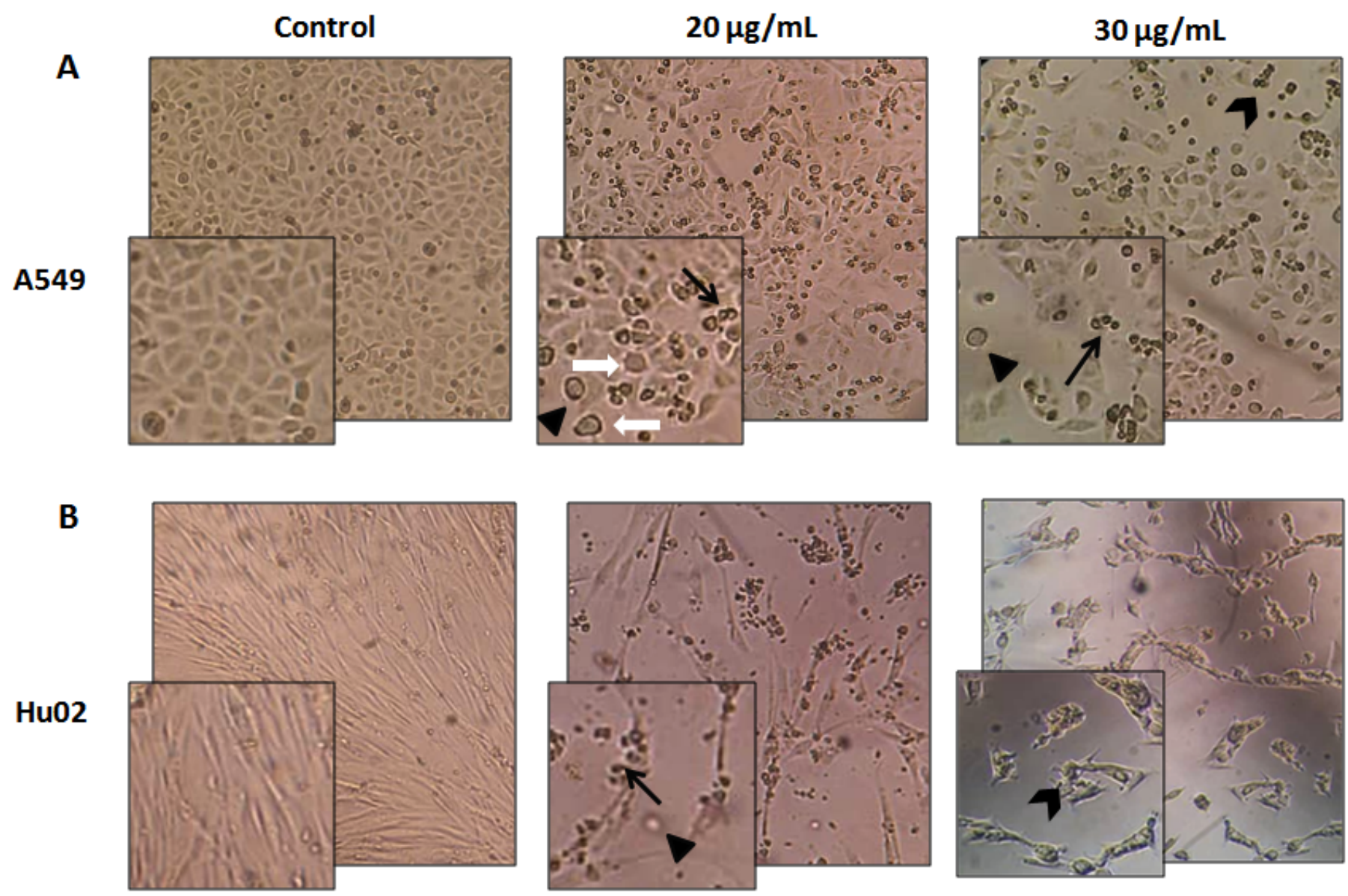

Figure 1. Morphological and cell growth assessment of $(\mathbf{A}) \mathrm{A} 549$ and (B) Hu02 cells treated with P. persicus crude venom. Morphological differences in the cells were observed under Labomed TCM 400 inverted phase contrast microscope (magnification $100 \times$ ) after treatment with 20 and $30 \mu \mathrm{g} / \mathrm{mL}$ of $P$. persicus crude venom for 24 hours. Control shows the untreated cells. Irregular shape of the cells (A549 normal cells), cell rounding (filled triangles), cellular debris (arrowheads), apoptotic bodies (black arrows) and cytoplasmic blebbing (white arrows) are observable in the venom treated cells

of cells. In addition, cells were likely to detach from the surface and float on the medium.

\section{Cytotoxicity of $P$. persicus crude venom on lung cancer cells versus normal fibroblast cells}

Treatment of two cell lines with $P$. persicus crude venom at $3-50 \mu \mathrm{g} / \mathrm{mL}$ concentrations for 24 hours significantly decreased cell viability dose- and time-dependent manner, compared with control cells (Figure 2A). It is interesting that using the highest venom dose $(50 \mu \mathrm{g} / \mathrm{mL})$ or longer incubation period $(48$ hours), the cells were killed, supposedly by acute necrosis and no apoptotic bodies were observed (data not shown).

The $\mathrm{IC}_{50}$ for $\mathrm{A} 549$ and $\mathrm{Hu} 02$ cells after 24 hours treatment were 18.37 and 16.40, respectively. Therefore, A549 cancer cells with higher $\mathrm{IC}_{50}$ were more resistant to crude venom comparing to normal fibroblast cells.

\section{Effect of $P$. persicus crude venom on caspase -3 and caspase- 9 activities}

To understand if apoptosis was the reason of cell death and to explain the pathway leading to it, the activities of caspase-3 and caspase-9 (aspartate-specific cysteine proteases) were estimated in A549 and $\mathrm{Hu} 02$ cell lines by substrate cleavage assay. Determination of a chromophore organic compound, which is the cleavage product of substrate DEVD-p-NA at a wavelength of $405 \mathrm{~nm}$, indicates the caspase- 3 enzyme activity in the cells. The same protocol but different substrate (LEHDp-NA) was used for assaying the activity of caspase- 9 enzyme.

As shown in Figure 2B, treatment of A549 and $\mathrm{Hu} 02$ cell lines with the $\mathrm{IC}_{50}$ concentrations of $P$. persicus venom at 12 and 24 hours increased the caspase- 3 and caspase- 9 activities comparing untreated cells in a time-dependent manner. The activities of caspase- 3 and caspase- 9 peaked at 24 hours after 

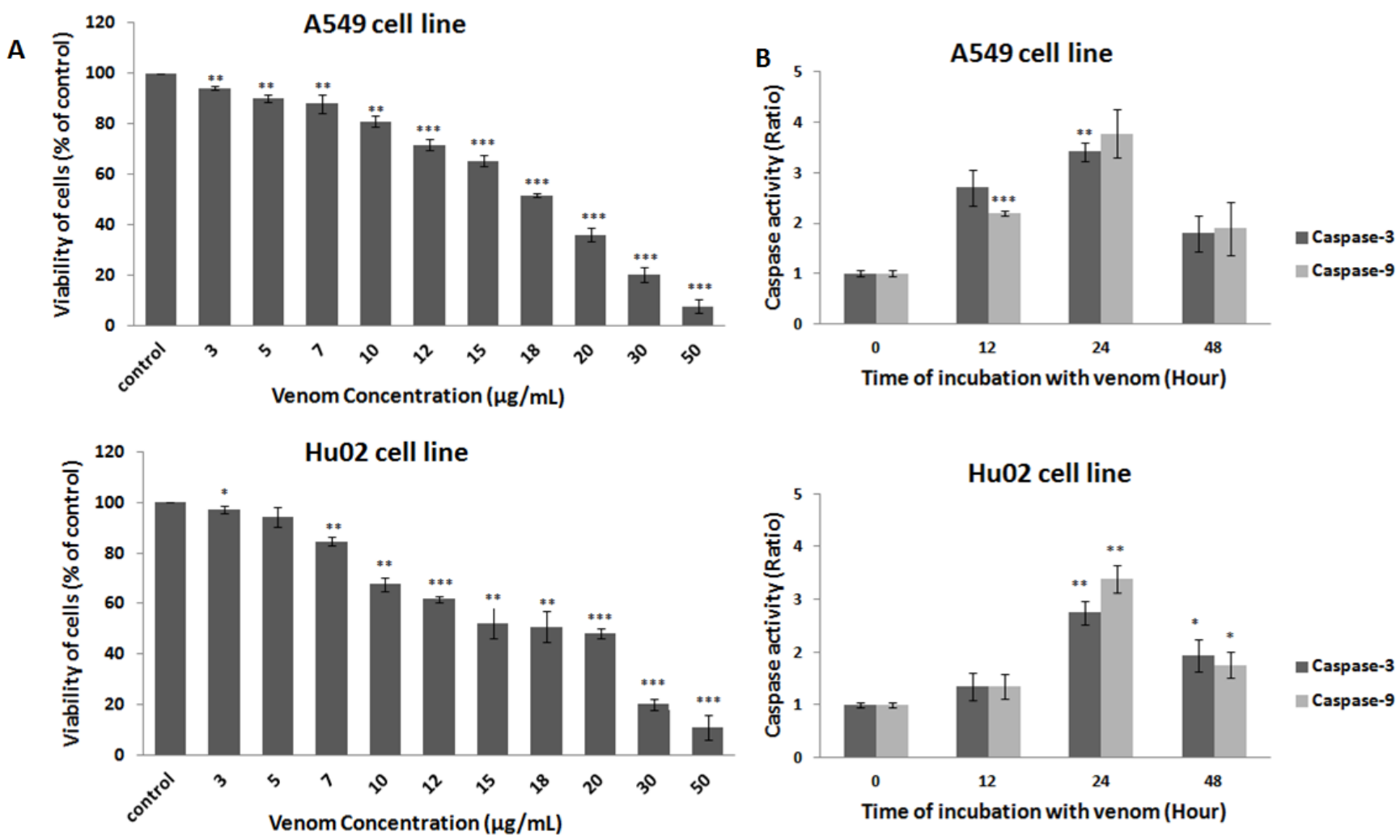

Figure 2. Effects of $P$. persicus venom on cell viability and caspase-3 and caspase- 9 activities compared to untreated cell. (A) Cytotoxic activity of $P$. persicus crude venom on A549 and Hu02 cells after 24 hours of treatment with different venom concentrations. The viability of cells was estimated by MTT assay. (B) Activities of caspase- 3 and caspase- 9 enzymes in A549 and Hu02 cells after venom treatment. The cell lines were treated with IC50 concentrations of $P$. persicus venom for 12, 24 and 48 hours and harvested separately. Activities of caspases were determined by substrate cleavage assay. All data were presented as mean \pm S.D $(n=3)$. Statistical significance versus control (*p $<0.05 ; *^{*} p<0.01$; $\left.* * * p<0.001\right)$.

venom treatment. However, there is a drop in their activities at 48 hours after treatment in both cell lines. The decrease in the caspase activities is probably due to the higher number of cell death after 48 hours.

These results suggest that $P$. persicus venom induces its cytotoxic effects through apoptosis in a caspase-dependent mechanism in A549 and Hu02 cell lines.

\section{Fractions isolation from crude venom of P. persicus}

First using an analytical reverse phase HPLC (C18 column, $100 \AA, 5 \mu \mathrm{m}, 4.6 \times 150 \mathrm{~mm}$ ) the chromatographic profile of $P$. persicus venom components was obtained in a linear gradient of solvent B (acetonitrile/0.1\% TFA). To be able to split the peaks and collect the venom components individually, the exact ratios of solvents for the peaks were estimated and a semistep gradient elution condition was optimized. The fractions related to 34 peaks were collected manually and as it is clearly observed in Figure 3, some peaks were eluted in specific ratio of solvents.

\section{Cytotoxicity analysis of HPLC fractions of $P$. persicus venom}

The lyophilized fractions were dissolved in DMEM medium and A549 and $\mathrm{Hu} 02$ cells were treated with $20 \mu \mathrm{g} / \mathrm{mL}$ of each fraction for 24 hours. The cell viability was analyzed using MTT assay.

The fractions that reduced the survival rate of cells in less than $85 \%$ were considered to be toxic fractions. Figure $4 \mathrm{~A}$ shows the morphological changes and the extent of cell death for A549 and Hu02 cells 24 hours after incubation with $20 \mu \mathrm{g} / \mathrm{mL}$ of HPLC fractions 15, 21, 23 and 29. Other fractions did not induce considerable changes in the viability and morphology of cells (data not shown). The toxic fractions exerted significant inhibitory effects on the growth rate of A549 cells. The survival rates of A 549 cells following treatment with $20 \mu \mathrm{g} / \mathrm{mL}$ of fractions $15,21,23$ and 29 were $10.73 \%, 9.57 \%, 11.25 \%$ and $27.50 \%$ of untreated cells, respectively. Fraction 21 exhibited the highest cytotoxicity for A549 cells and the least cytotoxicity towards $\mathrm{Hu} 02$ cells. The survival rates of $\mathrm{Hu} 02$ cells treated with $20 \mu \mathrm{g} /$ $\mathrm{mL}$ of fractions 15, 21, 23 and 29 were $22.50 \%, 69.88 \%, 6.54 \%$ and $20.47 \%$ of untreated cells, respectively (Figure $4 \mathrm{~B}$ ). 


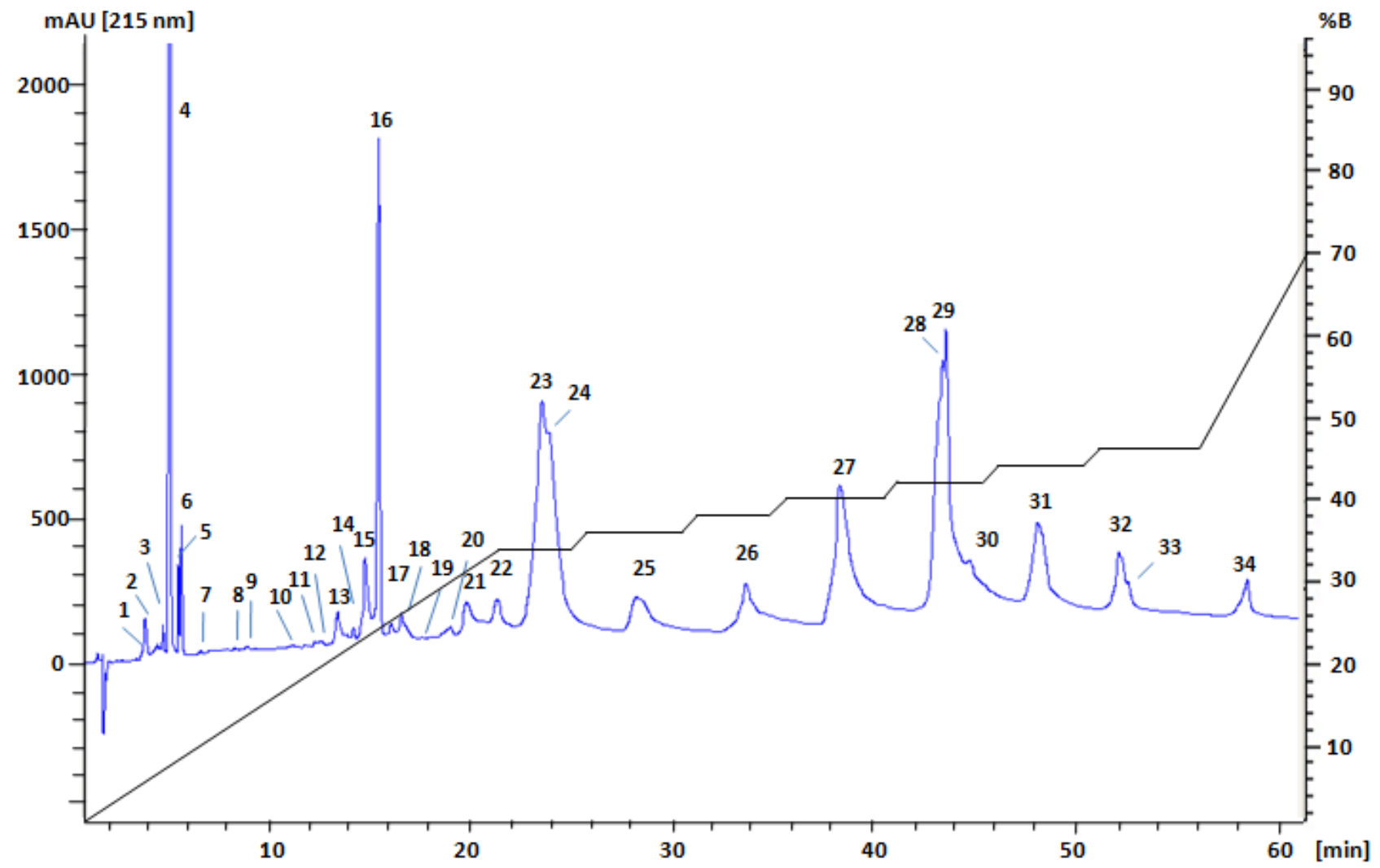

Figure 3. Reverse phase chromatographic separation of $P$. persicus venom. Lyophilized venom (10 mg) dissolved in $2 \mathrm{~mL}$ of double-distilled water was injected into C18 column continuously $(100 \mu \mathrm{L}$ of venom extract for each injection) and eluted using a semi-step gradient of acetonitrile/0.1\% TFA (\%B). Thirty-four protein fractions according to their peak distribution were collected manually, lyophilized and used for further analysis.

The molecular masses of the protein fractions responsible for the cytotoxic activity of venom were evaluated using SDS PAGE analysis (Figure 4C). Fraction 15 did not show any signal on the gel, which supposed to be a small peptide $(<10 \mathrm{kDa})$ or a nonprotein/non-peptide compound of the venom. Fraction 21 showed a single band on SDS-PAGE analysis with a molecular mass between 25 and $35 \mathrm{kDa}$ and fraction 23 contained low molecular mass peptides with molecular masses between 11 and $17 \mathrm{kDa}$. Fraction 29 contained high molecular mass proteins (between 48 and $63 \mathrm{kDa}$ - Figure $4 \mathrm{C}$ ). Using the proteome map of P. persicus venom as a reference we are able to get additional information about the proteins present at the cytotoxic fractions [16].

\section{Analysis of HPLC fraction 21 of P. persicus venom}

In order to find out if the cytotoxic effect of the fraction 21 in cancer cells is accidental because of the non-specific factors (necrosis) or if it is specific, caspase-3 and caspase-9 activities and LDH release of A549 and $\mathrm{Hu} 02$ cells treated with various concentrations of this fraction were estimated.
As it is observed in Figure 5A, fraction 21 decreased the viability of A549 cells in a dose-dependent manner. By treating the cells with $30 \mu \mathrm{g} / \mathrm{mL}$ of this fraction, the cell viability decreased to $6.67 \pm 1.2 \%$. However, $\mathrm{Hu} 02$ cells were very resistant to this toxic fraction and after treatment with highest concentration $(30 \mu \mathrm{g} / \mathrm{mL})$ of fraction 21 , the viability of these cells was $47.89 \pm 2.87 \%$ compared to untreated cells. The caspase- 3 and caspase- 9 activities increased in A549 cells by increasing the concentration of fraction 21 , but the activities of these enzymes did not change in Hu02 cells when compared to untreated cells (Figure 5B).

Furthermore, the LDH release increased from the cells treated with different concentrations of fraction 21 in a dose-dependent manner (Figure 5C). As shown in Figure 5C, treatment of $\mathrm{Hu} 02$ cells with 5,10 and $20 \mu \mathrm{g} / \mathrm{mL}$ of fraction 21 caused the release of $20 \%, 33 \%$ and $56 \%$ total LDH, respectively. However, treatment of A549 cells with the same concentrations of fraction 21 , released only $14 \%, 18 \%$ and $24 \%$ total $\mathrm{LDH}$ into culture medium. Treatment of the cells with $30 \mu \mathrm{g} / \mathrm{mL}$ of fraction 21 caused massive release of $\mathrm{LDH}$ ( $83 \%$ of total LDH) in $\mathrm{Hu} 02$ cells comparing to $40 \% \mathrm{LDH}$ release in $\mathrm{A} 549$ cells. 
A
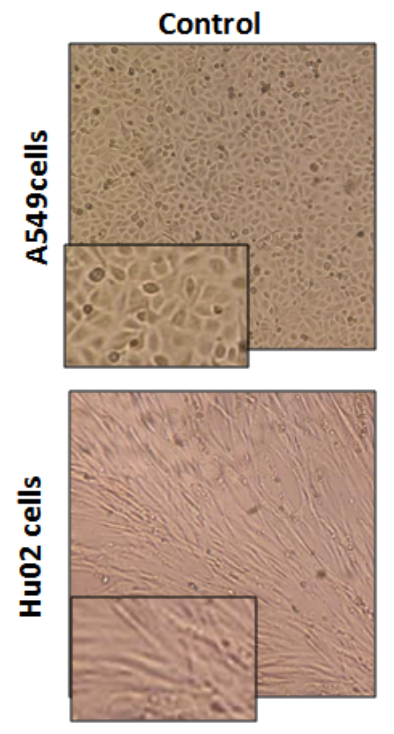

B

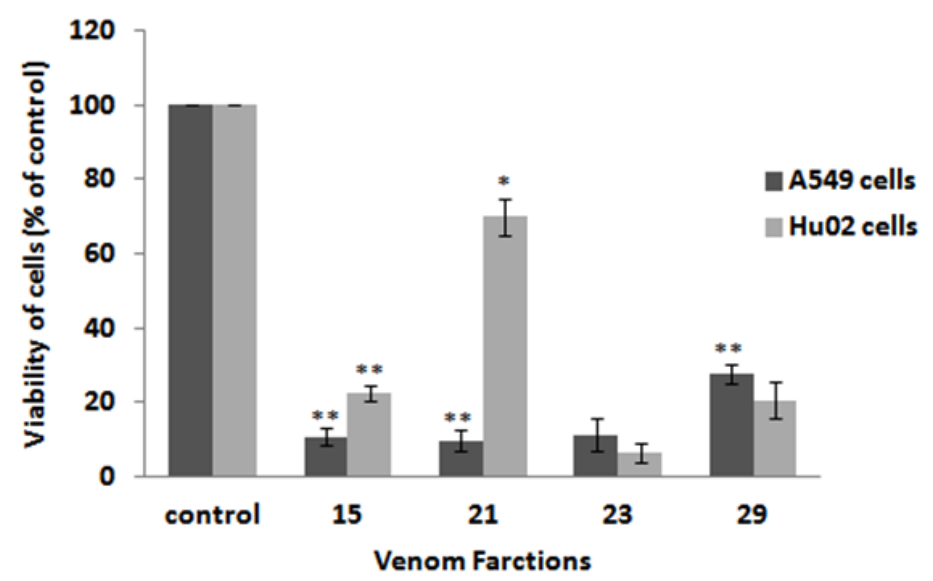

Fraction 15
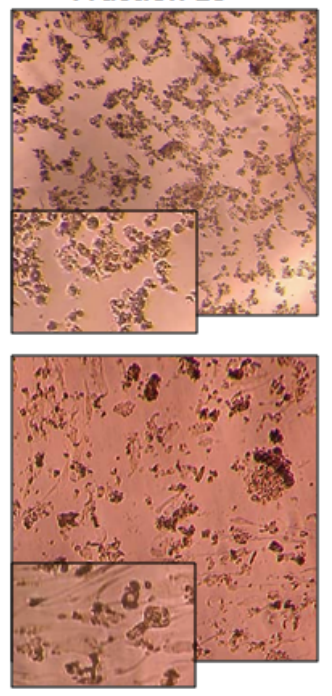
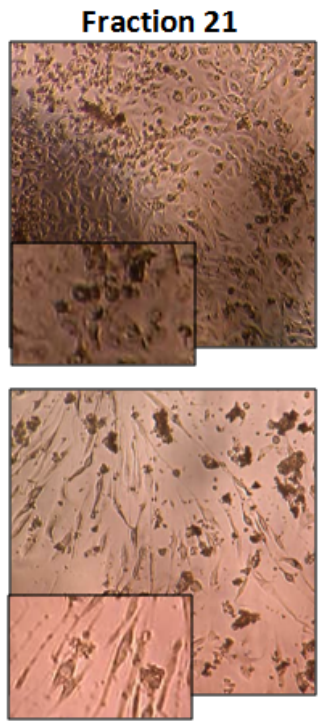

Fraction 23
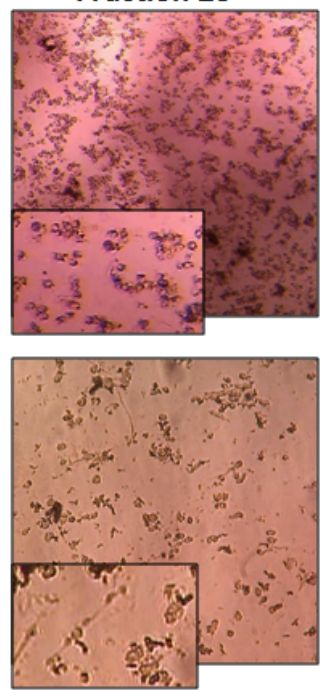

Fraction 29
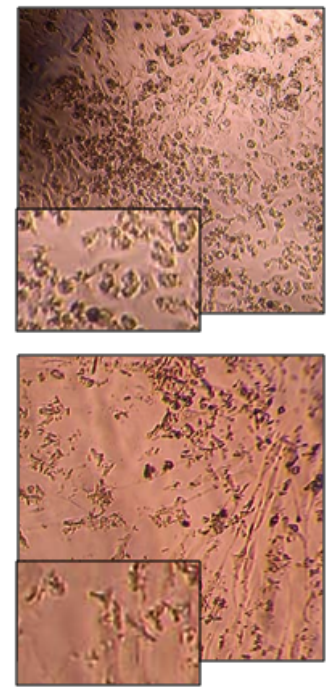
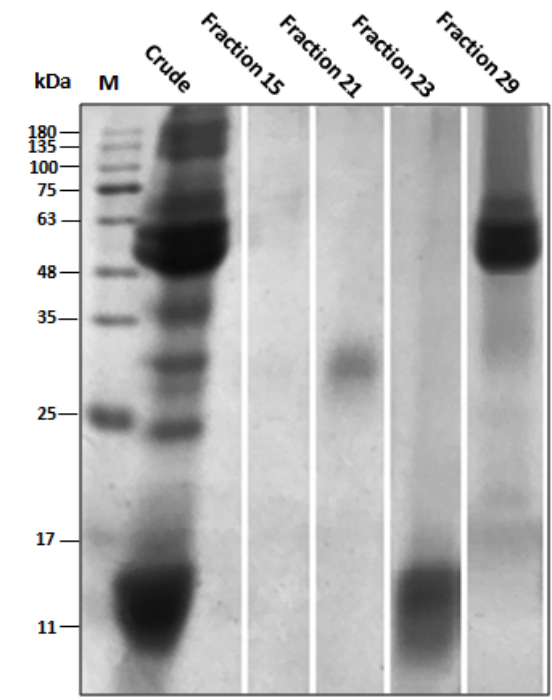

Figure 4. Analysis of cytotoxic fractions of $P$. persicus venom. (A) Morphological observation of A549 and Hu02 cells treated with HPLC fractions $15,21,23$ and 29 under phase-contrast inverted microscope (magnification 100x). The A549 and Hu02 cells were treated with $20 \mu \mathrm{g} / \mathrm{mL}$ isolated fractions and incubated for 24 hours in 96-well plates. The morphological changes in the cells treated with cytotoxic fractions are displayed here. Untreated cells comprise the control group. (B) Effect of cytotoxic fractions of $P$. persicus venom on A549 and Hu02 cells. The cells were treated with $20 \mu \mathrm{g} / \mathrm{mL}$ of fractions $15,21,23$ and 29 for 24 hours and the viability of the cells was evaluated by MTT test. Untreated cells comprise the control group. Values were presented as means \pm SD $(n=3)$. Statistical significance versus control $\left(*_{\mathrm{p}}<0.05\right.$; $*_{\mathrm{p}}<0.01$; $\left.*^{*} \mathrm{p}<<0.001\right)$. (C) SDS-PAGE analysis of cytotoxic fractions under reduced conditions. M: Molecular mass marker.

\section{Discussion}

The complex mixture that comprise snake venom components is responsible for numerous biological activities of venoms. Many studies on snake venom proved that some of its natural compounds have cytotoxic effects, which induce apoptosis in cancer cells by altering their cellular metabolism $[1,17]$. In fact, most of the drugs used for cancer treatment induce their effects through activation of essential factors of the apoptotic signaling pathways. Therefore, a compound of snake venom with ability to induce apoptosis in cancer cells is a potential candidate for an anticancer drug. Up to this moment, some drugs derived from venom peptides that inhibit the proliferation and invasion of cancer cells are already in preclinical or clinical phase studies [3].

The purpose of the current study was to evaluate the cytotoxicity of the $P$. persicus venom and its components on cancer and normal cells. The in vitro cytotoxicity test was applied to determine the anticancer activity of venom $[18,19]$. In this test, lung cancer cells (A549) and normal fibroblast cells (Hu02) were exposed to different concentrations of crude venom and the cell viability was estimated using MTT assay. The $\mathrm{IC}_{50}$ of venom for each cell line was calculated. The results showed that the crude venom significantly reduced the viability of A549 and Hu02 cells in a concentration-dependent manner. 

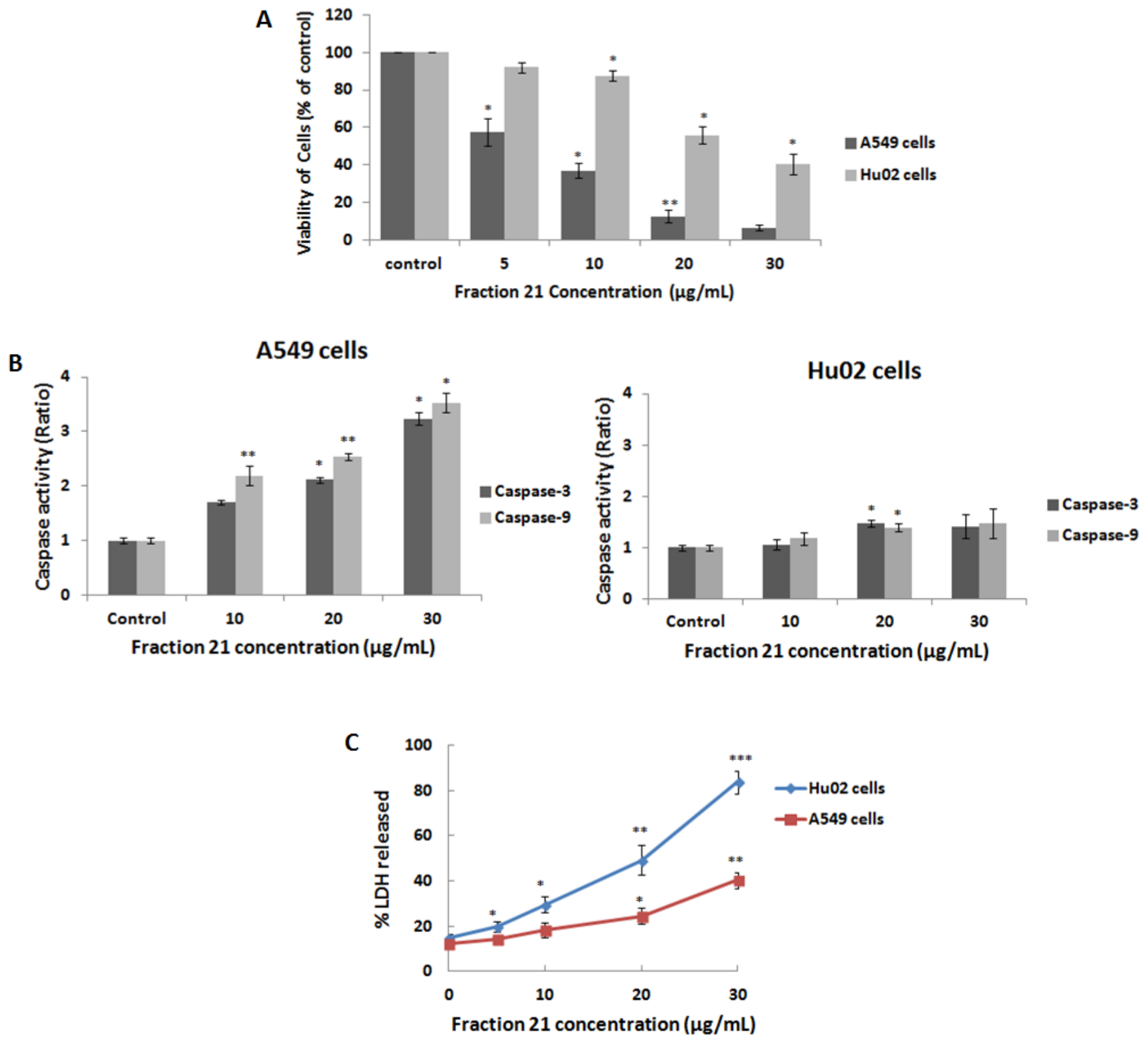

Figure 5. Analysis of cell viability and caspase- 3 and caspase- 9 activities after treatment of A549 and Hu02 cells with different concentrations of fraction 21 of P. persicus venom. (A) The dose-dependent effect of fraction 21 on the cell viability of A549 and Hu02 cell lines. (B) The caspase- 3 and caspase- 9 activities of the A549 and $\mathrm{Hu} 02$ cells after treatment with different concentrations of fraction 21. Relative caspase- 3 and caspase-9 activities were estimated as a ratio of the cells treated with fraction 21 to untreated cell (control). (C) Effects of different concentrations of fraction 21 on the percentage of LDH released in A549 and Hu02 cells 24 hours after incubation. All data were presented as mean \pm S.D $(n=3)$. Statistical significance versus control $(* \mathrm{p}<0.05 ; * * \mathrm{p}<0.01 ; * * * \mathrm{~F}<0.001)$.

The variation in the cytotoxicity is due to the complexity of the venom components and the presence of different specific receptors on the cell surfaces [20-22].

Since the crude venom contains various components, cell death happens in different mechanisms of action. Although $P$. persicus crude venom has significant cytotoxic activity, since it kills normal cells (Hu02) as well as cancer cells (A549), we cannot conclude that the crude venom has anticancer activity, unless we could identify a venom component which selectively kills cancer cells with no effects on normal cells [11].

In order to determine the specific venom compounds that caused the cytotoxicity effects and morphological changes in cancer cells, venom components were separated using RP-HPLC. The cytotoxic potential of the $P$. persicus venom fractions were examined on A549 and Hu02 cells. Fractions 15, 23 and 29 caused a drop in the cell viability of both cancer and normal cells. However, cell treatment with $20 \mu \mathrm{L} / \mathrm{mL}$ of fraction 21 significantly induced cell death in A549 cancer cell with little cytotoxic effects on $\mathrm{Hu} 02$ normal cells.

Our results indicate that fraction 21 increases cell death in A549 cells in a dose-dependent manner. This was accompanied by an increased level of caspase- 3 and caspase- 9 activities. Increased caspase- 3 and caspase- 9 activities indicated that the fraction 21 can exert its inhibitory effects through mitochondria 
dysfunction and cellular stress, leading to apoptosis. Naja oxiana crude venom and cardiotoxin III (CTX III) isolated from Naja naja atra venom induce apoptosis in cancer cells thorough this mechanism [22-24]. Treatment of A549 cells with $30 \mu \mathrm{L} / \mathrm{mL}$ of fraction 21 induced $40 \% \mathrm{LDH}$ release and a 3.5 fold increase in the level of caspase-3 activity and 3.2 fold increase in the level of caspase- 9 activity, which confirmed that $30 \mu \mathrm{L} / \mathrm{mL}$ of this fraction induces both apoptosis and necrosis in A549 cells. This phenomenon is due to the mitochondrial membrane permeability. If a toxin damages the mitochondrial inner membrane and the permeability transition pores (PTP) are formed on the membrane, this causes the loss of membrane potential and the induction of necrotic death. If the same toxin increases the mitochondrial outer membrane permeabilization (MOMP) as well, then mitochondrial outer membrane is damaged causing the release of cytochrome $\mathrm{C}$ and apoptosis [23].

The level of LDH release and caspase- 3 and caspase- 9 activities in $\mathrm{Hu} 02$ and $\mathrm{A} 549$ cells treated with $5,10,20 \mu \mathrm{L} / \mathrm{mL}$ of fraction 21 had pertinent effects: low caspase-3/9 activities and higher LDH release in $\mathrm{Hu} 02$ cells and high caspase-3/9 activities and lower LDH release in A549 cells respectively. Therefore, these concentrations of fraction 21 lead to necrosis in $\mathrm{Hu} 02$ cells, whereas in A549 cells the same concentrations caused apoptosis. Interestingly, $10 \mu \mathrm{g} / \mathrm{mL}$ of fraction 21 showed the most promising result with approximately $63 \%$ cell death in A549 cancer cells compared to the control group. The mechanism by which this fraction decreased the A549 cell proliferation is thorough caspase activation, and the increased activity of caspase- 3 and caspase- 9 suggests that this fraction induces its cytotoxic effects in cancer cells via intrinsic apoptotic pathway [24].

The $P$. persicus venom proteome map has been prepared by Ali et al. [16] using two-dimensional polyacrylamide gel electrophoresis (2D-PAGE). In order to predict the HPLC fraction 21, this protein fraction on one-dimensional SDS-PAGE and the P. persicus venom protein proteome map on 2D-PAGE were analyzed.

The protein fraction 21 had a single band with molecular mass between 25 and $35 \mathrm{kDa}$. The proteins on $2 \mathrm{D}$ gels with similar molecular masses are SVMP (P-I), CRiSP and kallikrein [16]. CRiSPs are non-enzyme snake venom cysteine-rich secretory proteins that act as L-type $\mathrm{Ca}^{2+}$ and cyclic nucleotide-gated (CNG) channel-blocking toxins in some species [25-27]. No apoptotic effects for this protein have been reported so far. Therefore, CRiSP is not likely to be responsible for the cytotoxic activities observed here. Kallikrein enzymes, a subgroup of serine proteases, are involved in various biological processes such as digestion, blood coagulation, neurotransmission, and protein post-translational modifications. It was shown that crotalase - a kallikrein-like enzyme isolated from the venom of Crotalus adamanteus - inhibited the growth of B16 melanoma cells in vivo through defibrinogenation of mice, but this enzyme does not have a direct cytotoxic or cytostatic effect on cancer cells in vitro [28]. SVMPs are the snake venom hemorrhagic metalloproteinases that have different biological properties. They act as prothrombin activator [29], possess proteolytic activity leading to degradation of protein aggregates [30], hemorrhagic activity [31,32] and proinflammatory and apoptotic activities [33-36]. It has been proved that graminelysin I from Trimeresurus gramineus snake venom, a P-I SVMP, induces apoptosis in human umbilical-vein endothelial cells by degradation of extracellular matrix [37]. A P-I SVMP from Bothrops pauloensis snake venom (BpMP-II), also inhibited the adhesion of endothelial cells and in vitro angiogenesis [38]. Menaldo et al. [39] isolated a 22.9 $\mathrm{kDa}$ P-I metalloprotease from Bothrops atrox snake venom and confirmed it by RP-HPLC and SDS-PAGE.

Fraction 21 has cytotoxic and apoptotic activities and presents a molecular mass of $\sim 25-30 \mathrm{kDa}$, that is expected to be a P-I SVMP with a proteinase domain [40]. The results of the present study indicate that this fraction in a low dose $(10 \mu \mathrm{g} / \mathrm{mL})$ has high cytotoxic activity against lung cancer cells. However, in higher doses it may provoke necrosis in normal fibroblast cells, which could be due to the high toxicity of this fraction for cells.

Although the data gathered from this study is useful, it is not enough to characterize the protein. Further investigation should be performed to reveal the biochemical properties of HPLC fraction 21 and the details about its mechanism of action that leads to cell death in lung cancer cells.

\section{Conclusion}

Various toxins of $P$. persicus venom showed potential direct cytotoxic effects on lung cancer and normal fibroblast cells. However, fraction 21 at low concentrations displayed promising anticancer properties by inducing apoptosis in lung cancer cells. Therefore, this protein should be analyzed more extensively, since it may provide new perspectives for drug development.

\section{Abbreviations}

2D-PAGE: two-dimensional polyacrylamide gel electrophoresis; CNG: cyclic nucleotide-gated; DMEM: Dulbecco's modified Eagle's medium; DMSO: dimethylsulfoxide; FBS: fetal bovine serum; $\mathrm{IC}_{50}$ : half-maximal inhibitory concentration; LAAO: L-amino acid oxidase; LDH: lactate dehydrogenase; MOMP: mitochondrial outer membrane permeabilization; Pen-Strep: penicillin-streptomycin; PTP: permeability transition pores.

\section{Acknowledgments}

Authors would like to thank all the members of Venomous Animals and Antivenom Production Department and Immunology Department of Razi Vaccine and Serum Research Institute (RVSRI) for their excellent support. Authors acknowledge the scientific assistance of A. Zare Mirak Abadi.

\section{Availability of data and materials}

All data generated or analyzed during this study are included in this published article. 


\section{Funding}

This work was supported by a grant of Razi Vaccine and Serum Research Institute (RVSRI) (no. 7-18-18-087-950639).

\section{Competing interests}

The authors declare that they have no competing interests.

\section{Authors' contributions}

ZSN and HG analyzed and interpreted the biochemical data regarding the cytotoxicity effects of the venom. ZSN and FT prepared HPLC fractions of venom. BS and MS performed the in vitro cytotoxicity assays. All authors read and approved the final manuscript.

\section{Ethics approval}

Not applicable.

\section{Consent for publication}

Not applicable.

\section{References}

1. Calderon LA, Sobrinho JC, Zaqueo KD, De Moura AA, Grabner AN, Mazzi M V., et al. Antitumoral activity of snake venom proteins: New trends in cancer therapy. BioMed Research International. 2014;2014.

2. Vyas VK, Brahmbhatt K, Bhatt H, Parmar U. Therapeutic potential of snake venom in cancer therapy: current perspectives. Asian Pacific Journal of Tropical Biomedicine. 2013 Feb [cited 2019 Jan 15];3(2):156-62. Available from: http://linkinghub.elsevier.com/retrieve/pii/S2221169113600428

3. Ma R, Mahadevappa R, Kwok HF. Venom-based peptide therapy: insights into anti-cancer mechanism. Oncotarget. 2017;8(59):100908-30. Available from: http://www.oncotarget.com/fulltext/21740

4. Pal SK, Gomes A, Dasgupta SC, Gomes A. Snake venom as therapeutic agents: From toxin to drug development. Indian Journal of Experimental Biology. 2002;40(12):1353-8.

5. Nagai $\mathrm{H}, \mathrm{Kim} \mathrm{YH}$. Cancer prevention from the perspective of global cancer burden patterns. Journal of Thoracic Disease. 2017;9(3):448-51.

6. Jami MS, Hemati S, Salehi Z, Tavassoli M. Association between the length of a CA dinucleotide repeat in the EGFR and risk of breast cancer. Cancer Investigation. 2008;26(4).

7. Arruebo M, Vilaboa N, Sáez-Gutierrez B, Lambea J, Tres A, Valladares $M$, et al. Assessment of the evolution of cancer treatment therapies. Cancers. 2011;3(3):3279-330.

8. Hoelder S, Clarke PA, Workman P. Discovery of small molecule cancer drugs: Successes, challenges and opportunities. Molecular Oncology. 2012;6(2):155-76.

9. Ahmadi M, Jafari R, Marashi SA, Farazmand A. Indirect role of microRNAs and transcription factors in the regulation of important cancer genes: A network biology approach. Cellular and Molecular Biology. 2015;61(6):100-7.

10. Kerkkamp H, Bagowski C, Kool J, van Soolingen B, Vonk FJ, Vlecken D. Whole snake venoms: Cytotoxic, anti-metastatic and antiangiogenic properties. Toxicon. 2018 Aug [cited 2018 Dec 2];150:39-49. Available from: https://linkinghub.elsevier.com/retrieve/pii/S0041010118301855

11. Moga MA, Dimienescu OG, Arvătescu CA, Ifteni P, Pleş L. Anticancer activity of toxins from bee and snake venom-an overview on ovarian cancer. Molecules. 2018;23(3):1-21.

12. Salehi-Najafabadi Z, Li B, Valentino V, Martin H, Yu Y, Wang Z, Kashyap $P$, and Yu Y. 2017. Extracellular loops are essential for the assembly and function of polycystin receptor ion channel complexes. J. Biol. Chem. 292, 4210-4221.
13. Carmichael J, Degraff WG, Gazdar AF, Minna JD, Mitchell JB. Evaluation of a Tetrazolium-based Semiautomated Colorimetrie Assay: Assessment of Radiosensitivity1. CANCER RESEARCH. 1987 [cited 2018 Nov 27]. Available from: https://pdfs.semanticscholar.org/ a304/8c649eb58a4167f7733a9f1974278a1efb7e.pdf

14. Mosmann T. Rapid colorimetric assay for cellular growth and survival: application to proliferation and cytotoxicity assays. Journal of immunological methods. 1983 Dec 16 [cited 2019 May 13];65(1-2):55-63. Available from: http://www.ncbi.nlm.nih.gov/pubmed/6606682

15. Laemmli. Cleavage of Structural Proteins during the Assembly of the Head of Bacteriophage T4. Nature. 1970;227:561.

16. Ali SA, Jackson TNW, Casewell NR, Low DHW, Rossi S, Baumann K, et al. Extreme venom variation in Middle Eastern vipers: A proteomics comparison of Eristicophis macmahonii, Pseudocerastes fieldi and Pseudocerastes persicus. Journal of Proteomics. Elsevier B.V.; 2015;116:10613. Available from: http://dx.doi.org/10.1016/j.jprot.2014.09.003

17. Gomes A, Bhattacharjee P, Mishra R, Biswas AK, Dasgupta SC, Giri $B$. Anticancer potential of animal venoms and toxins. Indian journal of experimental biology. 2010 Feb [cited 2018 Nov 27];48(2):93-103. Available from: http://www.ncbi.nlm.nih.gov/pubmed/20455317

18. López-Lázaro M. How many times should we screen a chemical library to discover an anticancer drug? Drug Discovery Today. 2015;20(2):167-9.

19. Nalbantsoy A, Karabay-Yavasoglu NU, Sayim F, Deliloglu-Gurhan I, Gocmen B, Arikan H, et al. Determination of in vivo toxicity and in vitro cytotoxicity of venom from the Cypriot blunt-nosed viper Macrovipera lebetina lebetina and antivenom production. Journal of Venomous Animals and Toxins including Tropical Diseases. 2012;18(2):208-16.

20. Bradshaw MJ, Saviola AJ, Fesler E, Mackessy SP. Evaluation of cytotoxic activities of snake venoms toward breast (MCF-7) and skin cancer (A-375) cell lines. Cytotechnology. Springer Netherlands; 2016;68(4):687-700. Available from: http://dx.doi.org/10.1007/s10616-014-9820-2

21. Pavel MA, Lam C, Kashyap P, Salehi-Najafabadi Z, Singh G, Yu Y. Chapter 16 Analysis of the Cell Surface Expression of Cytokine Receptors Using the Surface Protein Biotinylation Method. Methods Mol Biol. 2014;1172:185-92.

22. Lam C, Pavel MA, Kashyap P, Salehi-Najafabadi Z, Valentino V, Yu Y. Chapter 17 Detection of CXCR2 Cytokine Receptor Surface Expression Using Immunofl uorescence. Methods Mol Biol. 2014;1172:193-200.

23. Arakawa S, Nakanomyo I, Kudo-Sakamoto Y, Akazawa H, Komuro I, Shimizu S. Identification of a novel compound that inhibits both mitochondria-mediated necrosis and apoptosis. Biochemical and Biophysical Research Communications. Elsevier Ltd; 2015;467(4):1006-11. Available from: http://dx.doi.org/10.1016/j.bbrc.2015.10.022

24. Brentnall M, Rodriguez-Menocal L, De Guevara RL, Cepero E, Boise LH. Caspase-9, caspase-3 and caspase-7 have distinct roles during intrinsic apoptosis. BMC Cell Biology. 2013;14(1):1. Available from: BMC Cell Biology

25. Sanhajariya S, Duffull SB, Isbister GK. Pharmacokinetics of snake venom. Toxins. 2018;10(2).

26. Yamazaki Y, Brown RL, Morita T. Purification and cloning of toxins from elapid venoms that target cyclic nucleotide-gated ion channels. Biochemistry. 2002;41(38):11331-7.

27. Yamazaki Y, Koike H, Sugiyama Y, Motoyoshi K, Wada T, Hishinuma S, et al. Cloning and characterization of novel snake venom proteins that block smooth muscle contraction. European Journal of Biochemistry. 2002;269(11):2708-15.

28. Markland FS. Antitumor action of crotalase, a defibrinogenating snake venom enzyme. Seminars in Thrombosis and Hemostasis. 1986;12(4):284-90.

29. Kini RM. The intriguing world of prothrombin activators from snake venom. Toxicon. 2005;45(8):1133-45.

30. Willis TW, Tu AT. Purification and Biochemical Characterization of Atroxase, a Nonhemorrhagic Fibrinolytic Protease from Western Diamondback Rattlesnake Venom. Biochemistry. 1988;27(13):4769-77.

31. Rael ED, Lieb CS, Maddux N, Varela-Ramirez A, Perez J. Hemorrhagic and mojave toxins in the venoms of the offspring of two mojave rattlesnakes (Crotalus scutulatus scutulatus). Comparative Biochemistry and Physiology - Part B: Biochemistry and. 1993;106(3):595-600. 
32. Molina $O$, Seriel RK, Martinez M, Sierra ML, Varela-Ramirez A, Rael ED. Isolation of two hemorrhagic toxins from Crotalus basiliscus basiliscus (Mexican West coast rattlesnake) venom and their effect on blood clotting and complement. International Journal of Biochemistry. 1990;22(3):253-61.

33. Gasanov SE, Dagda RK, Rael ED. Snake Venom Cytotoxins, Phospholipase A2s, and Zn2+-dependent Metalloproteinases: Mechanisms of Action and Pharmacological Relevance. J Clin Toxicol. 2014 [ cited 2018 Nov 28]. Available from: https:/www.ncbi.nlm.nih.gov/pmc/articles/PMC4060629/ pdf/nihms582682.pdf

34. Gutiérrez JM, Rucavado A. Snake venom metalloproteinases:Their role in the pathogenesis of local tissue damage. Biochimie. Elsevier; $2000 \mathrm{Sep}$ 10 [cited 2018 Nov 28];82(9-10):841-50. Available from: https://www. sciencedirect.com/science/article/pii/S0300908400011639?via\%3Dihub

35. Zhang Y, Chen X, Gueydan C, Han J. Plasma membrane changes during programmed cell deaths. Cell Research. Nature Publishing Group; 2018;28(1):9-21. Available from: http://dx.doi.org/10.1038/cr.2017.133

36. Han YP, Lu XY, Wang XF, Xu J. Isolation and characterization of a novel P-Il class snake venom metalloproteinase from Trimeresurus stejnegeri. Toxicon. 2007;49(7):889-98.
37. WU W Bin, CHANG SC, LIAU M-Y, HUANG T-F. Purification, molecular cloning and mechanism of action of graminelysin I, a snake-venomderived metalloproteinase that induces apoptosis of human endothelial cells. Biochemical Journal. 2001;357(3):719. Available from: http://www. biochemj.org/bj/357/bj3570719.htm

38. Achê DC, Gomes MSR, de Souza DLN, Silva MA, Brandeburgo $\mathrm{MIH}$, Yoneyama KAG, et al. Biochemical properties of a new PI SVMP from Bothrops pauloensis: Inhibition of cell adhesion and angiogenesis. International Journal of Biological Macromolecules. Elsevier B.V.; 2015;72:445-53. Available from: http://dx.doi.org/10.1016/j. ijbiomac.2014.08.050

39. Menaldo DL, Jacob-Ferreira AL, Bernardes CP, Cintra ACO, Sampaio S $\mathrm{V}$. Purification procedure for the isolation of a $\mathrm{P}$-I metalloprotease and an acidic phospholipase $A_{2}$ from Bothrops atrox snake venom. Journal of Venomous Animals and Toxins Including Tropical Diseases. 2015;21(1):114. Available from: http://dx.doi.org/10.1186/s40409-015-0027-6

40. Fox JW, Serrano SMT. Insights into and speculations about snake venom metalloproteinase (SVMP) synthesis, folding and disulfide bond formation and their contribution to venom complexity. FEBS Journal. 2008;275(12):3016-30. 